UDC 338.242.2

JEL Classification: M31, O31, O10

DOI 10.35433/ISSN2410-3748-2021-1(28)-2

Dr Dembowska Barbara

Państwowa Uczelnia im. Stefana Batorego, Skierniewice, Polska

Kalinichenko Olena Ph.D., Senior Lecturer

Department of Economics, Management and Marketing and Hotel and Restaurant Business Zhytomyr Ivan Franko State University http: //ORCID 0000-0002-5213-1649

\author{
Poita Iryna \\ Ph.D., Docent \\ Department of Economics, Management and Marketing \\ and Hotel and Restaurant Business \\ Zhytomyr Ivan Franko State University \\ http: //ORCID 0000-0003-2137-3706
}

\title{
CREATIVE MARKETING AS A TOOL OF INNOVATIVE DEVELOPMENT OF THE ECONOMY
}

The article identifies the most important areas of development of creative marketing, which are the result of creative "imagination" of the marketer. In essence, this is the freedom to make a marketing decision based on market conditions, experience, knowledge, consumer behavior in each market segment. Thus, a great responsibility in this case lies with the marketer, who must have a nonstandard thinking, the talent to creatively perceive the situation in the market and use them, as well as be able to choose a non-traditional marketing option that would immediately attract consumers, make them stay longer near this product or its advertising. This is the main difference between creative and traditional marketing - the ability to attract the attention of the buyer, to surprise him. The marketer must have a lateral thinking, which is to shift from traditional thinking, breaking the

standard approaches to any particular idea, finding an original way to express it, creating something radically new. The article proposes a synthetic technology of innovation, which includes all components of the socio-economic system: society, economy and society and creates a sequence.

It is proved that the use of a creative marketing approach is reflected in the product and its characteristics: novelty of the product, non-standard product, purposefulness in use, development. The article reveals the essence, advantages and disadvantages of implementing creative marketing strategies, including anticipation strategy and reactive strategy. Introduction and use of a creative approach to marketing activities of the enterprise is a key element of modern entrepreneurship, 
which plays a key role in achieving goals. The right combination of creative approach and pragmatic view is the key to the effective functioning of the enterprise in modern market conditions. Key words: creativity, innovation process, creative marketing, foresight strategy, reactive strategy.

\section{КРЕАТИВНИЙ МАРКЕТИНГ ЯК ВАЖЛИВИЙ ІНСТРУМЕНТ ІННОВАЦІЙНОГО РОЗВИТКУ ЕКОНОМІКИ}

В статті визначені найважливіші напрямами розвитку креативного маркетингу, щуо полягають у результаті творчої «фантазї̈» маркетолога. По суті, ие свобода в прийнятті маркетингового рішення з урахуванням кон'юнктури ринку, досвіду, знань, поведінки споживача в кожному сегменті ринку. Таким чином, велика відповідальність в даному випадку лягає саме на маркетолога, який повинен мати нестандартне мислення, талант креативно сприймати, що відбуваються на ринку ситуації $і$ користуватися ними, а також

вміти вибрати такий нетрадииійний варіант маркетингу, який би відразу привернув споживача, змусив довще зупинитися біля даного продукту або його реклами. В ирому $i$ полягає основна відмінність креативного маркетингу від традииійного - вміння звернути на себе увагу покупия, здивувати його. Маркетолог повинен володіти латеральним мисленням, яке полягає в зміщенні від традиційного мислення, розриві стандартних підходів до будьякої певної ідеї, пошуку оригінального способу ї̈ вираження, створення чогось кардинально нового. В статті пропонуються синтетична технологія інноватики, яка включає всі компоненти сочіально-економічної системи: соціум, економіку і суспільство та створюють послідовність. Доведено, що використання креативного маркетингового підходу відображається в товарі та його характеристиках: новизна товару, нестандартність товару, иілеспрямованість у використанні, розвиток. В статті розкрито сутність, переваги та недоліки впровадження стратегій креативного маркетингу, зокрема стратегію передбачення та реактивну стратегію. Впровадження та використання креативного підходу до маркетингової діяльності підприємства виступає основним елементом сучасного підприємництва, яка відіграє ключову роль в досягненні иілей. Правильне поєднання творчого, креативного підходу та прагматичного погляду є запорукою ефективного функціонування підприємства в сучасних ринкових умовах господарювання.

Ключові слова: креатив, креативність, інноваційний процес, креативний маркетинг, стратегія передбачення, реактивна стратегія.

Problem statement. Today, many companies no longer perceive marketing not as a separate management function, but as a separate concept in the field of management of innovative development of the organization and the state, implementing marketing technologies. It is worth noting that innovative development is inextricably linked with the formation of new mechanisms of interaction between producers and consumers.

Any innovation begins with a creative idea, it is creativity that is the starting point for innovation. Very often innovations are put on a par with creativity. 
In reality and culture, creativity is considered and perceived more broadly than the technological element of creativity, because it is, as mentioned above, a new and not yet fully understood by most.

Analysis of recent research and publications. Juler A. [2], Dulkin A. V. [3], were engaged in creative research in marketing. Morozova I.G. [7], Beer P., Bernstein D., etc.

Formulation of the objectives of the article. The purpose of the article is to analyze the features of creative marketing as a means of increasing the innovative development of the economy.

Presentation of the main material. The popularity of the use of the terms "creative" and "creativity" in relation to new original ideas appeared in the conditions of our reality at the end of the XX century. Creative in the broadest sense of the word is interpreted, first of all, as the creation or application of original or previously unused ideas, action or process of creating something new; on the other hand, the creative is the creative potential of a person or team (firm), sometimes - the creative process or product [6].

This task has become especially relevant recently. In this regard, special importance is given to such important and at the same time deeply unknown, and therefore often not taken into account factors of economic development, as the creative or otherwise creative resource of enterprises. An example is the successful operation of such companies in the world economy as Google, H\&M, Samsung, Nokia, Apple, $P \& G$, Unilever. In many respects, the competitive advantages and high indicators of economic activity of these companies are achieved through the use of certain methods that promote the activation and attraction of quality creative resources underlying innovation.

Applying creativity or the ability to think outside the box to the activities of market participants is one of the main competitive advantages of successful companies, which are achieved through the use of a set of methods aimed at activating and attracting quality creative resources underlying innovation [2]. 
It was at the beginning of the twentieth century that innovation began to be seen as the most important means of overcoming cyclical crises. Innovations cease to be the object of management, limited exclusively to the field of scientific development. They began to concern not only technological processes, but also management methods, processes of research of concrete markets, etc. that forces to reconsider use of creative potential of the enterprises and the state. Innovations, which are based on a creative beginning, become a necessary condition for the survival of the enterprise in market conditions. The innovation process "covers all components of the socio-economic system (SES) - society, economy and state. A sequence is formed: marketing - policy - project - management "[1] (Fig. 1).

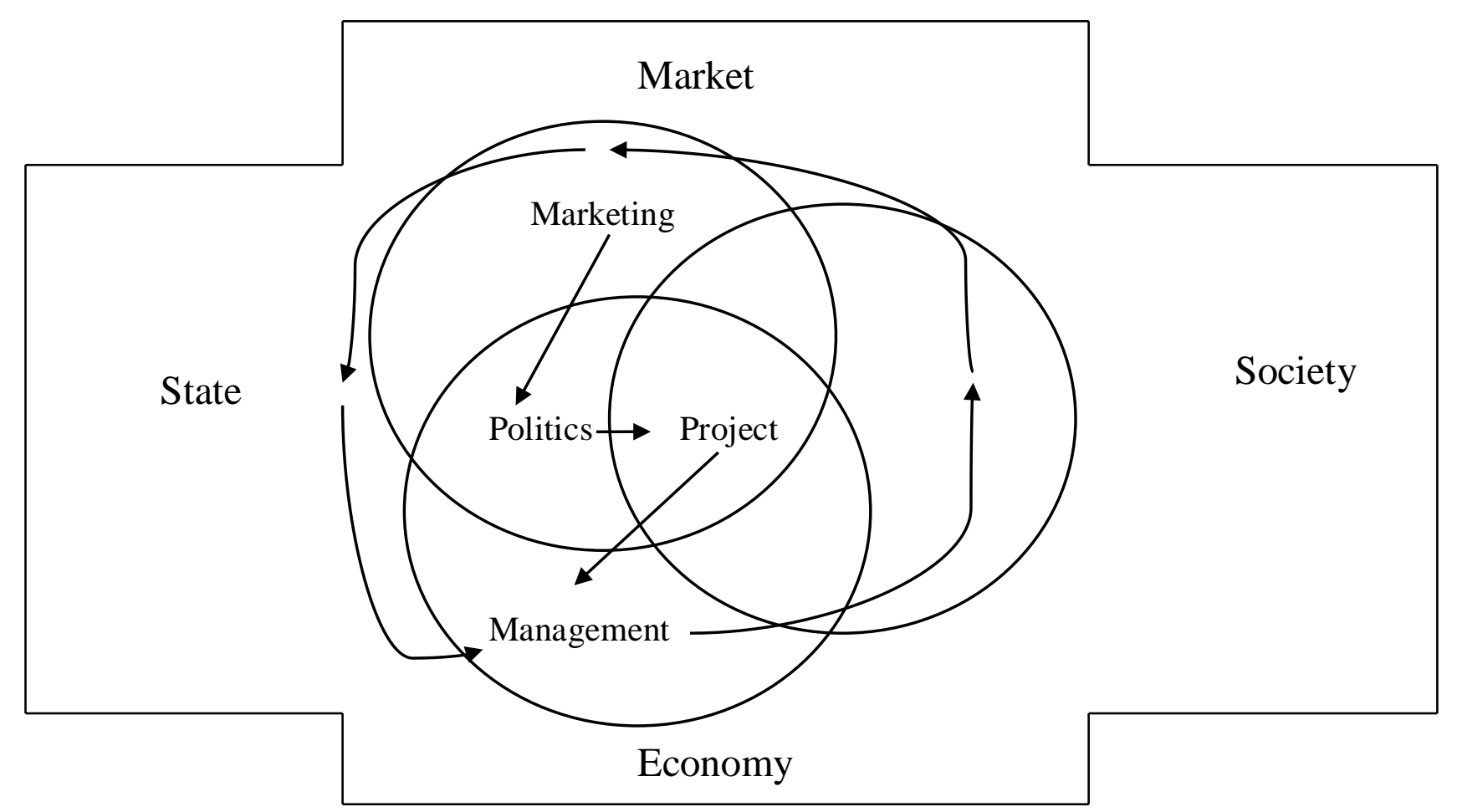

Fig. 1. Synthetic technology of innovation

Thus, marketing is an integral tool driving the innovative development of the economy. According to the results of the practice of using marketing tools in the economy in recent decades, the importance of the presence in all areas of marketing methods and tools, which are also based on the creative (creative) component, is rapidly increasing [8]. 
The use of the term "creative" and the characteristic "creativity" in relation to new original ideas became popular in the late twentieth century. In literary sources, "creativity" is used, as a rule, as an analogue of creativity, with the amendment that creativity is a type of activity, and creativity is a characteristic.

Creativity, therefore, is the ability to be creative, in the form of desire and the ability to create fundamentally new non-traditional ideas and solve problems using non-standard approaches. A single theoretical approach to understanding creativity has not been formulated. Some authors believe that creativity is a type of human activity aimed at a non-standard solution, which requires objective (social and material) and subjective personal conditions (knowledge, skills, creativity), and the result of which has novelty, originality, personal and social significance. Others determine it as the basis of human life, the highest level of activity [8].

Creative marketing, which is a search for original solutions that attract customers, is usually based on simple, low-budget promotions and ways to promote. At the same time, a large number of several unusual, extraordinary, creative solutions are used, due to which the maximum effect is actually achieved.

The basis of creative marketing technology can be determined by identifying the preferences of the creative type of audience, the criteria for possible changes in these preferences and ultimately - the creation of a creative strategy [3].

The following can be mentioned as features of creative marketing (Fig. 2).

Any innovation begins with the development of a creative product. The use of a creative marketing approach leaves an imprint on the created product, endowing it with unique characteristics. Such characteristics include the following:

1. Novelty of the product. The first sign of a creative idea underlying a product or service may be a new manufacturing technology, a change in the composition or configuration of the product itself.

2. Non-standard goods. The second feature is responsible for the destruction of existing standards, sometimes its application is expressed in the combination of incompatible (at first glance) components. 


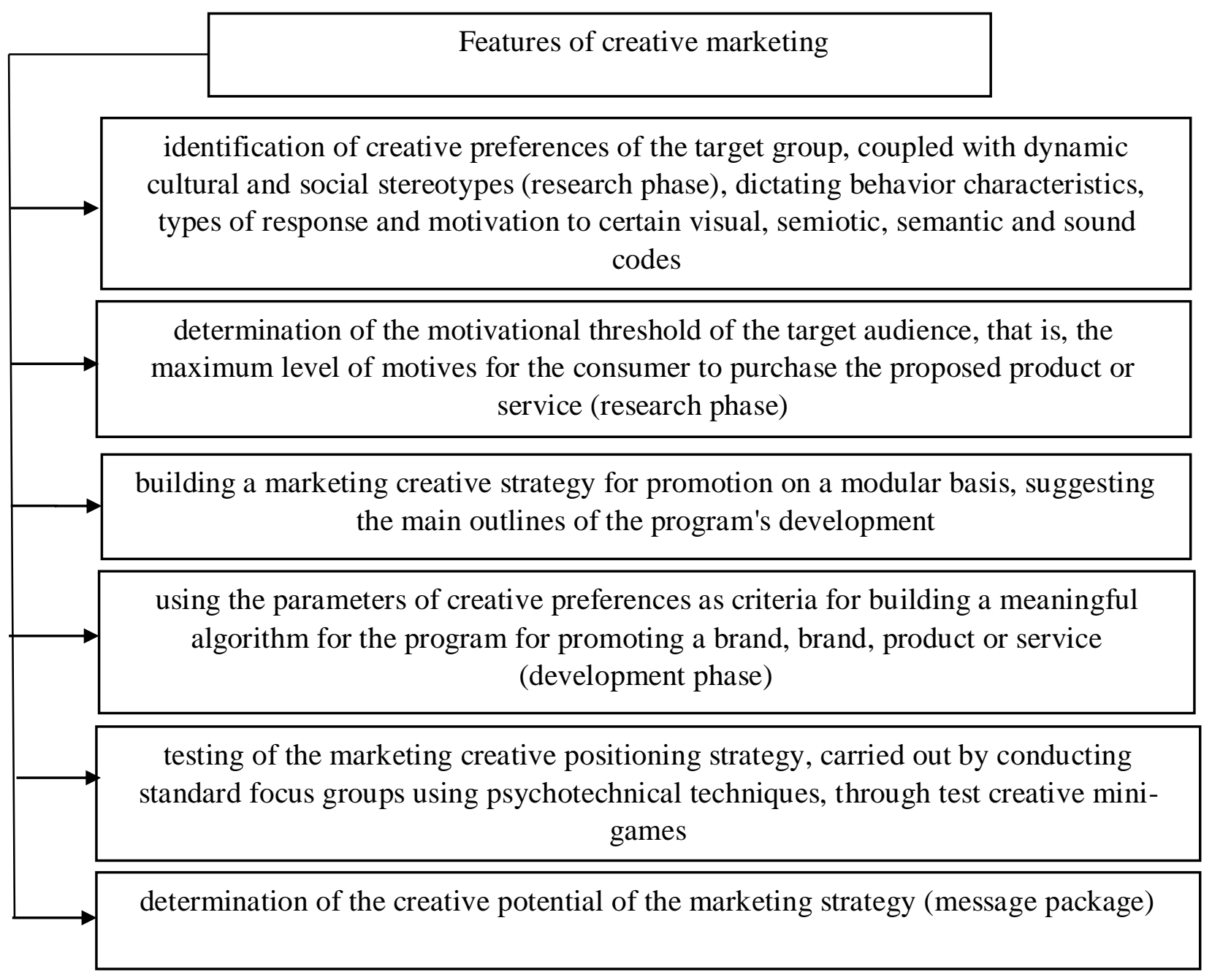

Fig. 2. Features of creative marketing

3. Expediency in use. There are many products on the market today that surprise with their combinations: a button for stress-resistant personal computer users or a binary wristwatch. All these products are undoubtedly new and non-standard, but not all of them directly benefit the consumer.

4. Development. Creating a product based on a creative idea should be aimed at further development of the company and the industry in which it operates (improving the image, developing new technologies and attracting investment) [4].

Creative marketing is productive only when it is focused on subsequent practical actions that ensure the growth and progress of both the enterprise and the economy as a whole. Process for the sake of process does not matter. From here, creativity, embodied in innovation, allows you to move from one stage of 
development to another, providing a new quality state and, accordingly, moving forward. Let's highlight the prerequisites that make possible the birth of innovation, including marketing:

First, it is necessary to have an understanding of the company's management that innovation is of particular importance in today's market economy. They are, on the one hand, indicators of the competitiveness of the enterprise, on the other provide this competitiveness.

Second, the company must be receptive to creative ideas, any of which must be considered in terms of its effectiveness and the benefits to the company in its implementation [1].

Third, "innovation in entrepreneurial activity must be considered as a phenomenon lying in the sphere of demand, not supply, because innovation changes the value and usefulness derived from the consumer of goods, it transforms economic resources into a new, more productive form "[4], which allows to gain a competitive advantage.

Fourth, it is especially important to unite the efforts of the entire staff of the enterprise to bring the creative solution to its innovative embodiment.

The moment of the need for marketing innovation can be considered as a certain period of time, due to objective economic laws, independent of us and our knowledge of them, when an innovation can be introduced to maintain (if it already exists) or achieve economic equilibrium. At the same time, the company can implement marketing innovations without the urgent need for them both on the part of the company and the market. Let's call such behavior of the enterprise as use of strategy of foresight or proactive marketing strategy. Another option is the introduction of marketing innovation in the presence of direct market needs or the needs of the enterprise due to environmental factors. In this case, the signal that there is a need for marketing innovation will be the emergence of any problems in the firm, whether a decrease in profits, a decrease in market share or, finally, the stagnation of the firm. This behavior of the company is a reactive marketing strategy. 
Each of these strategies has its advantages and disadvantages. Thus, the foresight strategy allows to solve the problem before it arose, ie the company does not incur any losses due to the delay in the implementation of marketing innovation, but in this case there is a risk of making a mistake in predicting the choice of marketing innovation. In a reactive strategy, the opposite is true.

Marketing innovations are divided into product and process. Product marketing innovations include:

- the use of new materials;

- application of new semi-finished products and accessories;

- development of fundamentally new products;

- use of new packaging;

- development of a new brand, etc.

Process innovations mean the use of new methods of organization of production and other processes of the enterprise [8].

In most cases, creative methods and tools for the implementation and use of marketing tools are developed directly by the company's own resources. Recently, however, there has been a tendency to "borrow" ideas from consumers themselves they try to meet the need with the means available to them, attracting their creative potential. Next, the idea is considered by the entrepreneur for the presence of a creative component according to the above criteria. "Borrowing" ideas from consumers, as an example of using a creative approach in the production of goods or services, is one of the many methods of creative marketing. For example, "guerrilla" marketing implies a rejection of standard, focus on the effectiveness of marketing policy in the absence of serious financial investments [5].

When using creative marketing, the company gains an undeniable advantage at each stage of the life cycle of a product or service. However, in the stages of saturation and decline, the application of such an approach becomes especially important. With declining sales growth and a significant increase in competition, the size of the entrepreneur's profit decreases, and the potential consumer becomes less 
receptive to advertising messages and gradually loses interest in the product or service. The use of creative marketing methods at these stages of the life cycle makes it possible to profitably modify the product, conduct an effective advertising campaign, extend the stage of saturation of the market with this product, thereby delaying its elimination.

Conclusions from this study. As part of the task of meeting the ever-emerging needs of customers in a more effective way than competitors, the use of creative marketing is the most effective.

The use of a creative approach by business entities is an integral part of modern business processes, gaining a significant role in achieving the goals. A reasonable combination of creativity and pragmatic approach is the key to effective functioning in the business environment of any entity - from a large company to an individual entrepreneur.

Thus, the identification of the relationship between creative marketing and innovative activities of enterprises allows us to highlight a new mission of the innovative economy through the activation, development and giving a positive direction to the processes taking place in the socio-economic system through the implementation of their creative ideas in innovations by enterprises, allowing at the same time to achieve progressive development of markets.

\section{REFERENCES}

1. Glushakova, T.I. (2014). Kreativnoye mishleniye $v$ reklame I chto emu sposobstvuyet [Creative thinking in advertising and that it contributes to]. Retrieved from: http://www.marketing.spb.ru/lib-comm/advert/ creative_mind.html [in Russian].

2. Juler, A. (2004). Creative Strategies in Advertising. St. Petersburg: Peter [in English]. 
3. Dulkin, A.V. (2014). Kreativnist firmi jak factor pidvischennya efektivnosti organizatcii [Creativity firm as a factor in increasing the efficiency organization]. Retrieved from: http://studok.net/book/html [in Ukrainian].

4. Imshenickaya, I. (2003). Creative in advertising. Moscow: RIP-holding [in English].

5. Kovrijenko, M.O. (2003). Creative in advertising. St. Petersburg: Peter [in English].

6. Kotelnikov, V.O. \& Bibikova, A.S. (2014). Tvorcheskiy marketing [Creative marketing]. Retrieved from: http://www.cecsi.ru/coach/marketing_creative.html [in Russian].

7. Morozova, I.G. (2003). Reklamniy kreativ: v poiskah nenavjazchivoy idei [Advertising creative: in search of an unobtrusive ideas]. Moscow: Gella-Print [in Russian].

8. Shubaeva, V.G. (2012). Kreativnyi marketing kak vazhnyi instrument innovatsionnogo razvitiia ekonomiki [Creative marketing as an important tool for innovative economic development]. Problemi sovremennoi ekonomiki-Problems of modern economics, vol. 4, 225-227. ]. Retrieved from: http: //www.m-economy.ru/ [in Russian].

Стаття надійшла до редакиії 20.04.2021

(C) Dembowska Barbara, Kalinichenko Olena, Poita Iryna 